\title{
El desarrollo de la cultura de gestión ambiental en estudiantes de secundaria en educación no formal con enfoque cultural y ecológico
}

\section{The development of environmental management culture in high school students in non-formal education with a cultural and ecological focus}

\author{
Natalia N. Demidova ${ }^{1}$, Natalya F. Vinokurova², Anna A. Loshchilova ${ }^{3}$, \\ Anastasia V. Zulkharnaeva ${ }^{2 a}$, Anna V. Matveeva ${ }^{5}$
}

Kozma Minin Nizhny Novgorod State Pedagogical University, Nizhny Novgorod, Russia $^{12345}$

(iD) ORCID ID: https://orcid.org/0000-0003-3536-7382
iD ORCID ID: https://orcid.org/0000-0002-2673-7700²
iD ORCID ID: https://orcid.org/0000-0002-6296-5516
iD ORCID ID: https://orcid.org/0000-0003-2210-8648
iD ORCID ID: https://orcid.org/0000-0002-0018-4052

Recibido: 03 de mayo de 2020

Aceptado 12 de octubre de 2020

\begin{abstract}
Resumen
El propósito del artículo es desarrollar el paradigma educativo de la cultura de la gestión ambiental para una educación avanzada orientada al desarrollo sostenible. Se establecen los fundamentos metodológicos de la investigación, presentados por enfoques metodológicos culturales-ecológicos, axiológicos, de actividad personal, integrales-situacionales. Se definen los principales métodos de investigación: análisis sistémico-estructural, generalización, sistematización, diseño y experimentación pedagógica. Se revelan los criterios, indicadores y métodos para diagnosticar la formación de los componentes de la cultura de gestión de la naturaleza. A partir de la investigación se desarrolló una metodología para la formación de una cultura de gestión ambiental en el contexto de la educación no formal, que incluye el objetivo, el contenido, las etapas y la tecnología de las situaciones integrales de orientación cultural. Para implementar esta metodología en la práctica educativa, se desarrolló un programa de actividades para "equipos verdes" escolares: "Estamos en el paisaje cultural de las fincas de nuestra tierra natal”, se revela su objetivo, contenido, se muestra la interconexión de las secciones del programa con la tecnología de situaciones integrales culturalmente orientadas. Se presentan los resultados de un experimento pedagógico organizado en los sitios experimentales de la Universidad de Minin. Los resultados del experimento, en el que participaron 360 estudiantes de secundaria, permitieron sacar una conclusión sobre la eficacia de la formación de una cultura de gestión ambiental entre los estudiantes en el contexto de la educación no formal de orientación cultural y ecológica.
\end{abstract}

Palabras clave: cultura, ecología, paisaje cultural, educación, educación no formal, tecnologías pedagógicas, enfoque integral. 


\begin{abstract}
The purpose of the article is to develop the educational paradigm of the culture of environmental management for advanced education aimed at sustainable development. The methodological foundations of the research are established, presented by cultural-ecological, axiological, personal-activity, integral-situational methodological approaches. The key research methods are defined: system-structural analysis, generalization, systematization, design, and pedagogical experiment. Criteria, indicators and methods for diagnosing the formation of the components of the culture of nature management are revealed. Because of the research, a methodology for the formation of a culture of environmental management in the context of nonformal education was developed, including the goal, content, stages and technology of culturally oriented integral situations. To implement this methodology in educational practice, a program of activities for school "green teams" was developed: "We are in the cultural landscape of estates of our native land", its purpose, content is revealed, the interconnection of the sections of the program with the technology of culturally oriented integral situations is shown. The results of a pedagogical experiment organized at the experimental sites of Minin University are presented. The results of the experiment, in which 360 high school students took part, made it possible to draw a conclusion about the effectiveness of the formation of a culture of environmental management among students in the context of non-formal education of cultural and ecological orientation.
\end{abstract}

Keywords: culture, ecology, cultural landscape, education, non-formal education, pedagogical technologies, integral approach.

\title{
Introduction
}

At present, human activities related to the development of nature are becoming a global factor that alters the face of the planet and aggravates environmental problems. The current level of natural resources consumption has led to a worldwide phenomenon - exceeding the capacity of natural ecosystems. Nature is a resource that has substantial economic importance and sustains life. The more intensely humankind exploits the planet adapting nature to its needs, the more urgent the problem of developing the culture of rational environmental management is (Ghaffari \& Tonkaboni, 2020). Scientists claim that the ecological crisis is fundamentally a crisis of the culture of human civilization. Obviously, we should develop the values of a new culture that should ensure the preservation of the natural foundations of life and sustainable development. An essential step in the development of this culture and building a "desired future" was the UNESCO International Conference "Culture: the Key to Sustainable Development," held in May 2013 in Hangzhou (China). The Hangzhou Declaration "Culture and Sustainable Development” (2013) was adopted at this conference. This document states that culture, as a human activity, should overcome a systemic crisis caused by the interaction between humans and nature and the problems of environmental management. Education is to play a unique role in solving this problem as one of the means of "developing creative and 
effective solutions to environmental problems." This idea was expanded in the paper of the Summit on Sustainable Development (September 2015) - “Transforming Our World: The 2030 Agenda for Sustainable Development.” According to this document, "culture is the driver and vector of sustainable development" and plays a vital role in developing education for environmental sustainability (Sustainable Development Goals, n.d.). Thus, the modern concepts of the transition to sustainable development emphasize the need for integrating culture into national and international politics as one of its strategic elements and into all educational systems as the most significant social institution. Today, education is part of the social practices of personal development and becomes a tool for the development of culture, society, and the individual. Therefore, we can talk about the emergence of a culture-centric educational paradigm.

\section{Literature review}

Russian scientists (Bakhtin, 2000; Bibler, 2002; Gessen, 1995; Gerder, 1977; Moiseev, 1999) noted that the culturological function of education becomes the leading one: it turns into a genetic matrix of the reproduction of society and acts as a means for personal development. In the context of this paradigm and as a polyfunctional category, culture becomes the core of the integration of various methods for understanding the world and human activities in it (through the languages of culture, such as science, ethics, aesthetics, philosophy, and religion) (Kurbatova et al., 2020, Galchenko, 2019). International researchers also highlight the dominant role of culture in education aimed at achieving sustainable development (KochharLindgren, 2018; Konchina, 2019; Sterling, 2014). The education system is considered as a special tool for the development of the cultural and ecological foundations of life (Sánchez Galera, 2020; Van Groenou, 2005). Other scientists point out the importance of subjective perceptual experience in solving cultural and environmental problems (Dillon, 2015; Loi \& Dillon, 2006). An essential aspect of implementing the cultural and educational paradigm is the formation of cultural competence since it underlies the evolution of society aimed at sustainable development (Van de Vijver \& Breugelman, 2008). Another paper (Hart et al., 2017) emphasizes the significant educational role of studying the cultural and ecological foundations of various ethnic groups and exploring the cultural heritage and cultural landscapes. Considering the findings of Russian and international researchers, let us emphasize the specifics of culture in the context of sustainable development (Demidova \& Vinokurova, 2019). Therefore, culture should encompass: a) new models of cognition congruous with the human; b) co-evolutionary relations and eco-humanistic values featuring the art of co-existence, 
promoting tolerance, developing empathy, and preserving natural, cultural, and landscape diversity; c) constructive activity when the constructing person and the constructed world represent a procedural unity, a mutually agreed world. These conditions form the basis of the culture of environmental management as a factor in the modernization of the education system. We define the culture of environmental management as a personal and socially significant quality of the individual. It is a method, measure, the result of cognition, assessment, and activities related to the cultural and economic development of the natural resource potential of a territory of various scales for its sustainable development (Vinokurova, 2014). The culture of environmental management is an element of the spiritual culture of humankind. At the same time, it encompasses all the diversity and richness of forms, methods, and techniques of nature management, a set of local, regional, and national traditions of use, transformation, reproduction, and conservation of the natural environment (Kochurov, 1995; Demidova \& Vinokurova, 2019). The culture of environmental management performs several functions: cognitive and informational, normative and value, adaptive and creative, project and predictive, as well as communicative and constructive (Vinokurova, 2014). They form the basis for the development, content, pedagogical technologies, and the stages of formation and diagnostics of the culture of environmental management as a strategic goal of education. Achieving this goal in adolescence is extremely important as it is when students develop their self-awareness, selfdetermination and form their views and relationships. Teenagers have a constant need for finding the meaning of life, determining their life prospects and the future of all humankind (Grimovskaya, 2020; Lobashev, 2020). These features explain adolescents' wish to participate in various kinds of non-formal education, which highlights their role in educational practices aimed at the formation of the environmental management culture (Makarova, Makarova, \& Korsakova, 2019; Timofeeva, 2019). The significance of cultural and environmental nonformal education has been considered in numerous papers (Dockry et al., 2015; Effendi, 2019; Loi \& Dillon, 2006; Panov \& Yasvin, 2000). The great potential of non-formal education is due to its socio-cultural focus, the use of active practice-oriented forms and methods of teaching, flexibility, mobility, and cooperation in solving the problems of environmental education (Priatna, 2020). As the diagnostics and the analysis of education practices have shown, adolescents have a low level of environmental management culture. In this regard, teachers point to the need to develop theoretical and methodological foundations for forming such culture. This contradiction determined the problem and the goal of our study: to create a methodological basis for the development of environmental management culture in adolescents in non-formal education. 


\section{Materials and methods}

\section{Theoretical and methodological basis}

Having studied the methodological foundations for the development of environmental management culture, we identified the following leading approaches. We considered the cultural and ecological approach as the methodological basis for the "diffuse penetration" of the environmental management culture into the system of non-formal education with a cultural focus. The implementation of the cultural and ecological approach qualitatively affects all aspects of the pedagogical system, enabling one to achieve the strategic goal - developing the culture of environmental management in adolescents. The main role here belongs to interdisciplinary areas of knowledge that study integral "human-inclusive" systems. The procedural aspect reflects the processes of mastering the value and semantic dominants of the socio-natural space by the individual representing a real cultural ecological education environment. The technological element implies the "saturation" of the educational environment of these landscapes with culturally oriented integral situations that encourage adolescents to adopt an environmentally conscious lifestyle and turns them into the subjects of the modern "noospheric co-evolutionary process” (Knyazeva, 2019: Shubinsky, 2010). The productive and evaluative aspect, which reflects social and personal components in the culture of environmental management, corresponds to the socialization and developing autonomy of adolescents.

The axiological approach reflects the fundamental values of the co-evolutionary interaction of a person with the environment. Within the framework of this approach, the personality interiorizes co-evolutionary values, transforms them into personal implications, that is, forms attitudes and values that become internal regulators of adolescent behavior.

The personal and activity approach focuses on the formation of the individual as a subject possessing the culture of environmental management, where culture, according to M.S. Kagan (2018), is considered “a way of natural and socially conditioned human activity.”

Within the integral and situational approach (Loshchilova et al., 2019, Demidova \& Vinokurova, 2019), adolescents study the cultural landscape through the dialectic of the whole and its part in the context of various culturally oriented integral situations of life perception, life awareness, and life creation. The algorithm for considering such situations includes the following stages:

1. Overall focus: An acquaintance;

2. Focus on the part: A dialogue;

3. Overall focus: Co-evolutionary synthesis. 
The interaction with all components of the cultural landscape is implemented using the integral model AQAL (All Quadrants, All Levels) developed by Wilber (2007) and Chuprikova (2009). Therefore, based on the previous studies (Vinokurova, 2014), we identified the following interrelated components of the culture of environmental management:

1. The cognitive component: knowledge about the relationship of a person with a spatially differentiated evolving environment based on the cognitive model of geo-ecology - a geo-eco-socio-system;

2. The value component: co-evolutionary values reflecting harmony and co-creation of a person and the environment at different spatial and territorial levels;

3. The regulatory component: a formal, external regulator that encompasses the provisions of environmental ethics and the ethics of environmental management in the context of the imperatives of sustainable development, the foundations of environmental legislation, regulatory prescriptions, and the restrictions of nature management. This component is connected with the value component as a prerequisite for the transition from external to internal regulators;

4. The behavioral component that determines the culture and eco-friendly actions in the environment;

5. The creative and activity component that sets the cultural ways of mastering the external environment by a person.

\section{Research methods}

As part of the experiment on developing environmental management culture in adolescents in non-formal education with a cultural and ecological focus, we devised the following methods to evaluate the formation of its components. We estimated the formation of the cognitive component based on the quality criteria for mastering ecological knowledge, which included such indicators as depth, generalization, and awareness. We defined these criteria in line with the ideas of I. Ya. Lerner (1978). We singled out two levels of knowledge: the level of facts and the level of substantial connections (from facts to generalization based on facts). We evaluated generalization according to the understanding of the problem essence and the systematization of knowledge. We defined awareness as an ability to operate with generalizations. Next, we devised diagnostic tasks to estimate the quality of geo-ecological knowledge acquisition based on the selected criteria.

We evaluated the value and normative component using the criteria of adolescents' attitudes to natural objects and phenomena. We selected the criteria in line with various 
approaches to defining the category of "personal attitude” (Myasishchev, 2004; Yadov, 2014) and the idea of a "subject-subject attitude to nature" (Deryabo \& Yasvin, 1996). We distinguished the following indicators of value attitudes towards nature: dominance, modality, and intensity.

The dominance criterion gives a formally quantitative characteristic of the attitude within the "insignificant - significant" opposition, reflecting the attitude to social and natural objects, processes, and phenomena. For this purpose, we used a modified method for estimating dominance (Deryabo \& Yasvin, 1996).

Modality is a criterion that gives a qualitative and substantial characteristic of a subjective attitude. Modality can be estimated within two oppositions:

1. “Object - Subject” (it represents the perception of an object and is determined by the possibility or impossibility of subjectifying a natural object);

2. "Pragmatic - Non-Pragmatic" (it describes the nature of the subject's interaction in the socio-natural environment).

Having unified these oppositions, we obtained four types of relations: object-pragmatic, object-non-pragmatic, subjective-pragmatic, and subjective-non-pragmatic (the Deryabo method, 1996). The intensity criterion characterizes the intensity of the relationship. To estimate the intensity of the subject's attitude to nature, we used the methodology "Naturaphil” (Deryabo \& Yasvin, 1996). Following these psychologists, we distinguished the perceptual-affective, cognitive, practical, and action components of intensity.

We evaluated the behavioral component according to the strength of the personal implications and activity attitudes of the individual. We identified three types of adolescents' attitudes that reflected the co-evolutionary ideas of the culture of environmental management. They ranged from the disharmony of limitless consumption to the creation, ensuring the wellbeing and harmony of human and the environment. The position of a consumer based on a pragmatic and technocratic attitude to nature with the emphasis on benefit with practically no reflexive awareness of nature management activities. The position of an empathizer that manifested itself in the subject's emotional response, understanding the complex role of nature, the formal approach to the use of natural resources, with a tendency to reflection. The position of a creator based on a new paradigm of relations within the unity of human and nature and reflecting the idea of cooperation, awareness of oneself as a part of society and nature, and one's role in the sustainable development of the planet as a whole and one's place of residence.

To determine the behavioral attitudes of adolescents, we developed diagnostic tasks in the test form (Demidova \& Vinokurova, 2019). We assessed the creative activity component 
according to the subjective experience of nature- and culture-related activities. We identified three levels of it. At the low level, students do not demonstrate or have poorly developed subjective experience of nature and culture-related activities aimed at solving and preventing environmental problems of nature management and reclamation of various territories. At the average level, adolescents perform such activities when it is required and always under the guidance of a teacher. At the high level, teenagers demonstrate considerable independence, the need for cooperation, and leadership qualities. We determined the levels of the subjective experience of nature and culture-related activities in adolescents based on the developed ecology-oriented cases (Demidova \& Vinokurova, 2019).

\section{Results}

Having identified the leading approaches, the functions, and the structure of the culture of environmental management, we determined the stages and the method for creating culturally oriented integral situations that would ensure its formation. The stages of the formation of the environmental management culture identified by us reflect the continuity of the development of the cultural landscapes environment (adaptation - comprehension - constructive and creative activity): 1. The cultural and adaptation stage involves the designation of the surrounding landscape; 2. The cultural and semantic stage implies awareness, comprehension, and selfdetermination within the cultural landscape; 3 . The cultural and creative stage focuses on creative activities aimed at the sustainable development of the cultural landscape. The sequence of the implemented stages is determined by the method of culturally oriented integral situations (Table 1).

\section{Table 1}

The interconnections of the development stages of the environmental management culture and the method of culturally oriented integral situations

No The development stages of The method of culturally oriented environmental management integral situations culture

\begin{tabular}{llll}
\hline 1 & The cultural and adaptation stage & $\begin{array}{l}\text { A cultural and adaptation integral } \\
\text { situation }\end{array}$ \\
2 & The cultural and semantic stage & $\begin{array}{l}\text { A cultural and semantic integral } \\
\text { situation }\end{array}$ \\
3 & The cultural and creative stage & $\begin{array}{l}\text { A cultural and creative integral } \\
\text { situation }\end{array}$
\end{tabular}

The cultural adaptation integral situation creates conditions for the aesthetic perception of life by students and their self-identification with the environment of cultural landscapes. 
Despite their specifics, each of the presented situations has a uniform solution algorithm within the integral and situational approach. We developed this algorithm relying on the principle of system differentiation proposed by Chuprikova (2009), Karopa (1999), and the integral model of Wilber (2007). It includes three stages reflecting the movement of thought from the whole to the part and, in the opposite direction, from the part to the whole. Stage 1 "Focus on the whole: An acquaintance” implies familiarizing oneself with the cultural landscape, its sensory cognition. Stage 2 "Focus on the part: A dialogue" involves identifying findamental relationships among landscape components. Stage 3 "Focus on the whole: Co-evolutionary synthesis” is the result of the interaction of the personality and the situation.

We implemented this method in the activities of school green teams and named this program "Our role in the cultural landscape of the country estates of our native land.” Green teams are the subjects of non-formal education operating in general education schools. They rely on the principles of voluntary participation, self-management, and care for the environment and people. The aim of the program is to create conditions for developing the culture of environmental management among the members of green teams based on the ideas of sustainable development, co-evolutionary values, ecological, cultural, and ethnocultural knowledge about the cultural landscape, as well as responsibility for preserving the natural foundations of life.

When selecting and structuring the content and transforming it into the personally significant one, we applied the following main principles: the eco-humanistic principle, the principle of historicism, predictability, and alternativeness; the cultural and creative principle; the principle of communication based on partnership and tolerance; and the principle of holistic perception of landscapes as the human living space.

The content of the program we proposed included three sections enabling the consistent development of cultural landscapes. The first section was "Immersion in the cultural landscape of the estates of the native land: The view of an aesthete” and implied studying the landscape appearance as well as aesthetics and images of manor houses. After studying it, adolescents created their ideal image. The second section "Cultural landscapes of the native land: The view of a connoisseur" focused on studying country estate landscapes in the context of their values, implications, as well as historical and cultural codes. The third section of the program "Cultural landscapes of estates of the native land: The view of the creator" contained information that helped teenagers understand the interdependence of the quality of life in the landscape and personal qualities of a person. It involved considering the strategy and tactics of environmental management and their role in landscape sustainability, the study of the natural environment of 
the manor houses as a natural and ecological resource. In addition to this, teenagers explored the influence of the material and spiritual culture of the landscape on the stable development of the local community and economy and realized that a person is responsible for creating their life. Each section of the program consisted of six topics. The first topic implied holistic consideration of the cultural landscape and its sensory cognition. The next four topics dealt with studying the natural, socio-economic, cultural, and subjective components of the landscape.

The learning outcome here was the "Road Map," representing the formula for sustainable use of natural resources in cultural landscapes of country estates and projects on future-design and eco-design (Lobashev \& Talykh, 2020). Such strong involvement allowed students to immerse gradually into the fascinating world of cultural landscapes of the country estates in the Nizhny Novgorod region (Table 2). 


\section{Table 2}

The interconnections in the content of the school green teams' activities within the program "Our role in the cultural landscape of the country estates of our native land" and culturally oriented integral situations

Topic No. Topic Name

\begin{tabular}{|c|c|}
\hline \multicolumn{2}{|c|}{ Topic No. Topic Name } \\
\hline Introduction & $\begin{array}{l}\text { The cultural landscape is the territory of my } \\
\text { life }\end{array}$ \\
\hline \multicolumn{2}{|c|}{$\begin{array}{l}\text { Section 1. Immersion in the cultural landscape of the estates } \\
\text { of the native land: the view of an esthete }\end{array}$} \\
\hline Topic 1 & $\begin{array}{l}\text { Aesthetics and images of cultural landscapes } \\
\text { of estates of the Nizhny Novgorod region }\end{array}$ \\
\hline $\begin{array}{l}\text { Topic } \quad 2, \\
3,4,5\end{array}$ & $\begin{array}{l}\text { Aesthetics and image of the natural, social, } \\
\text { cultural environment of the landscape, their }\end{array}$ \\
\hline Topic 6 & $\begin{array}{l}\text { My ideal image of the cultural landscape of the } \\
\text { estate of the Nizhny Novgorod region }\end{array}$ \\
\hline
\end{tabular}

Section 2. Cultural landscapes of the homesteads of the native land: the view of a connoisseur

Topic 7 The cultural landscape of the estate: cultural heritage, values and meanings

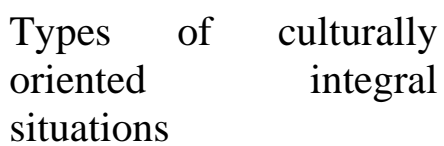

1.Cultural-adaptive integral situation

1.1. "Focusing on the Whole: Meeting"

1.2. "Focusing on the Part: Dialogue.

1.3. "Focusing on the Whole: Coevolutionary Synthesis"

2. Cultural and semantic integral situation

2.1. "Focusing on the Whole: Meeting"

Topic The role of nature, society, culture, the

$8,9,10,11$ subjective attitude of the individual in the formation of historical and cultural codes of the landscape of estates.

Topic 12 Portrait of the ideal user of the cultural landscapes of estates

Section 3. Cultural landscapes of estates of the native land: the view of the creator

Topic 13 The cultural landscape of estates: quality of life and sustainable development.

Topic 14, The influence of nature, society, culture and $15,16,17$ the subjective attitude of the individual on the quality of life in the landscape, its stability

Topic 18 My solutions: strategy and formulas for a sustainable future of cultural landscapes of estates
2.2. "Focusing on the

Part: Dialogue"

2.3. "Focusing on the Whole: Co-evolutionary Synthesis"

3. Cultural and creative integral situation

3.1. "Focusing on the Whole: Meeting"

3.2. "Focusing on the Part: Dialogue"

3.3. "Focusing on the Whole: Co-evolutionary Synthesis"

Teachers conducted one practical lesson a week according to the program. The rest of the time, the members of the green teams worked independently on their research projects. We systematized the obtained experimental data by performing quantitative and qualitative analysis. This allowed us to evaluate the effectiveness of developing environmental management culture in the members of the green teams. Therefore, the system of measures and 
criteria developed and the selected methods made it possible to reach the research goal. The experiment was carried out on the experimental sites of the Minin University - in schools, with 360 teenagers taking part in it.

At the beginning of the experiment, we determined a sample of adolescents participating in the experiment as well as the control groups of teenagers who did not belong to the green teams. We established that after the experiment on the formation of the cognitive component of the environmental management culture, the adolescents had the following results. The depth of knowledge acquisition in the control group increased from $45 \%$ to $54 \%$, and in the experimental group from $47 \%$ to $83 \%$. The generalization of environmental content in the control group increased from $21 \%$ to $37 \%$, and in the green teams from $24 \%$ up to $57 \%$. The level of awareness of ecological content increased by $7 \%$ in the control group and reached $24 \%$, whereas in the experimental group, it rose by $25 \%$ and estimated $44 \%$.

We analyzed the adolescents' questionnaires to identify their attitudes towards nature according to the dominance criterion and concluded that natural objects were not significant for the control group. For instance, only $7 \%$ of the respondents believed natural objects were important, $21 \%$ of the teenagers ranked them as of average importance, $29 \%$ - of low importance, and $45 \%$ of the students claimed natural objects were not significant. In the experimental group, the importance of natural objects increased four times and amounted to $27 \%$. Accordingly, $52 \%$ of the adolescents ranked natural objects of average importance, $21 \%$ - of low importance, while nobody believed they were not significant at all.

When analyzing the modality criterion, we estimated that $24 \%$ of the students in the experimental group had a subject-non-pragmatic relationship, while in the control group, this figure was only $4 \%$. At the same time, $57 \%$ of the adolescents in the control group demonstrated object-pragmatic relationships, with only $3 \%$ in the experimental group. The method for diagnosing the intensity of the subjective attitude to nature enabled us to reveal the fact that in the control group, up to $75 \%$ of the adolescents demonstrated affective and cognitive aspects of the subjective attitude to nature, while in the experimental group, the practical and action components of intensity prevailed (89\%).

We used three indicators to evaluate the development of adolescents' behavioral positions. Having analyzed the obtained results, we concluded that in the control group, the majority of adolescents had a consumer position (78\%), whereas in the experimental group, only a small part of adolescents (6\%) had this attitude. Most members of the green teams had a position of an empathizer (84\%). These results on the development of the subjective experience of nature and culture-related activities. In the control group, only $2 \%$ of adolescents 
demonstrated a high level of subjective experience. At the same time, $61 \%$ of students in the experimental group had the average level of subjective experience, and in the control group $15 \%$. We registered the low level of subjective experience in $14 \%$ of adolescents in the experimental group, and $83 \%$ in the control group. The results of the experiment allowed us to conclude on the effectiveness of the proposed method.

\section{Discussion}

Teenagers 11-14 years old took part in the study of the effectiveness of the formation of a culture of nature management. They are participants in non-formal formations organized in schools in Russia (Nizhny Novgorod). Thus, about 360 questionnaires were analyzed, which constituted a reference sample. During the research, limitations were identified. Among them are the educational preferences of adolescents regarding the study of cultural landscapes of estates and the implementation of environmental-friendly activities within this landscape. The number of participants in the experiment was limited to participants in non-formal formations. The pedagogical experiment took into account the consent of the subjects and the ethical norms of the research. The article presents an original experimental study, previously in domestic and foreign studies such a goal was not set.

The problem of developing a culture of nature management is relevant in the scientific and educational spheres related to the study of the environment and sustainable development of territories. Special attention in foreign studies is paid to "cultural knowledge, which is considered the key to good environmental management” (Satterfield et al., 2012), "the concept of human resources in environmental decision making (Wallace et al., 2020). A number of studies (Kanta Kochhar-Lindgren, 2018; Konchina, 2019; Sterling, 2014) note the dominant role of culture in the implementation of environmentally oriented activities to achieve sustainable development, the formation of subjective experience and competence as tools for the development of cultural and environmental interactions with the environment (Sánchez Galera, 2020, Van Groenou, 2005). The authors of the article agree with the positions presented in these studies, focusing on the value-semantic and activity aspects of the culture of human interaction with the environment.

The authors of the article believe that the totality of goals and values that determine the axiological basis of the culture of environmental management are based on the concept of ecocentrism, ideas of coevolution and sustainable development, cultural and ecological imperative, which is reflected in our research (Loshchilova et al., 2019a; Loshchilova et al., 2019b; Demidova and Vinokurova, 2019). The materials of the article related to the concept, 
function, structure of the culture of nature management, its value-normative aspect are based and develop the results of previously conducted scientific-geographical and psychologicalpedagogical research (Mamedov, 2009; Moiseev, 1999; Kochurov, Lobkovsky Smirnov, 2020; Kochurov, 2014; Deryabo \& Yasvin; 1996). At the same time, the analysis of scientific works allows us to conclude that the problem of the formation of a culture of environmental management in non-formal school formations in Russian psychological, pedagogical and methodological research has not previously been raised. Foreign studies also reflect only certain aspects of this problem.

The study was aimed at overcoming this contradiction and consisted of: substantiating the concept of the culture of nature management in the psychological, pedagogical and methodological aspects; selection of criteria, indicators and methods for diagnosing the formation of the culture of environmental management of schoolchildren; development and implementation of a methodology for the formation of a culture of environmental management of students in non-formal education in the practice of schools, which are experimental sites of Minin University; implementation of the program of work of "green teams" into school practice "We are in the cultural landscape of estates of our native land".

\section{Conclusion}

In this study, we formulated the conceptual foundations for the development of the culture of environmental management in adolescents in non-formal education with cultural and ecological focus. We defined the culture of environmental management and highlighted its structural components and its functions in modern advanced education. In addition to this, we revealed the content, procedural, technological, productive, and evaluative aspects of the development of the culture of environmental management, which integrally reflect the diversity of cultural concepts and the significance of the formation of all spheres of personal consciousness.

Also, we presented the program of activities of school green teams aimed at the development of the culture of environmental management in adolescents. We devised an apparatus for evaluating the culture of environmental management in adolescents and experimentally verified the effectiveness of this method in non-formal education with a cultural and ecological focus. In sum, this study is planned to be developed in the direction of developing teaching and educational modules for informal associations aimed at developing a culture of environmental management for children of preschool and primary school age. 


\section{Acknowledgements}

The study was supported by a grant from the Russian Foundation for Basic Research, project 19-013-00749 competition code A "Research of the theoretical foundations of the development of eco-oriented activities of schoolchildren in a cultural landscape.” The authors would like to thank the teachers of the experimental sites at the schools in Nizhny Novgorod (Russia) A. A. Burlak, Yu. R. Kraeva, I. M. Aminkaeva, O. V. Shilova, S. V. Ovchinnikova, O. A. Dubnevskaya.

\section{References}

Bibler, V. S. (2002). Conceptions. Moscow: RGGU. https://books.google.com.ua/books/about/\%D0\%97\%D0\%B0\%D0\%BC\%D1\%8B\%D 1\%81\%D0\%BB\%D1\%8B.html?id=9LE4AAAAMAAJ\&redir_esc=y

Brandist, C. (2000). Materializing Bakhtin. The Bakhtin Circle and Social Theory. Oxford: Macmillan Press. doi:10.1057/9780230501461

Chuprikova, N.I. (2009). Consciousness in the functional system of mental reflection and regulation of behavior and activity. Methodology and History of Psychology, 1, 113129. Retrieved from http://mhp-journal.ru/eng/2009_v4_n1_06

Demidova, N.N., Vinokurova, N.F. (2019). Designing an ecologically oriented lifestyle of a student's personality in the cultural landscape: Theoretical and methodological discourse. Monograph. N. Novgorod: OOO Kirilitsa. https://elib.bsu.by/handle/123456789/231218

Deryabo, S.D., Yasvin, V.A. (1996). Environmental Pedagogy and Psychology. Rostov-onDon: Feniks. Retrieved from https://mir.zavantag.com/geografiya/13652/index.html

Dillon, J., Rickinson, M., Teamey, K., Morris, M., Choi, M.Y., Sanders, D., Benefield, P. (2017). The value of outdoor learning: Evidence from research in the UK and elsewhere. The School Science Review, 87(320), 107-111. Retrieved from https://www.researchgate.net/publication/287621860_The_value_of_outdoor_learning Evidence_from_research_in_the_UK_and_elsewhere

Dillon, P. (2015). Education for Sustainable Development in a Cultural Ecological Frame. In R. Jucker, R. Mathar (Eds). Schooling for Sustainable Development in Europe. Schooling for Sustainable Development, Vol. 6. Cham: Springer. doi:10.1007/978-3319-09549-3_7

Dockry, M.J., Hall, K., Van Lopik, W., Caldwell, C.M. (2015). Sustainable development education, practice, and research: An indigenous model of sustainable development at 
the College of Menominee Nation, Keshena, WI, USA. Sustainability Science, 11(1), 127-138. doi:10.1007/s11625-015-0304-X

Effendi, T.D. (2019). Local wisdom-based environmental education through Kikigaki method: Japan experience and lesson for Indonesia. 12-th International Interdisciplinary Studies Seminar: Environmental Conservation and Education for Sustainable Development, 239. doi:10.1088/1755-1315/239/1/012038

Galchenko, A.S. (2019). Features of motivational structure of civil activity of teenagers with different status of civil identity. Vestnik of Minin University, 7(3), 8. Retrieved from https://cyberleninka.ru/article/n/osobennosti-motivatsionnoy-struktury-grazhdanskoyaktivnosti-podrostkov-s-raznym-statusom-grazhdanskoy-identichnosti

Gerder, I.G. (1977). Ideas on the Philosophy of the History of Mankind. Moscow: Nauka.

Ghaffari, R., \& Tonkaboni, M.A. (2020). Citizen participation policy making for environmental issues: a literature review. Journal of Southwest Jiaotong University, 55(3). Retrieved from http://jsju.org/index.php/journal/article/view/627

Grimovskaya, L.M. (2020). Development of child's cognitive abilities in project activity on environmental subjects. Vestnik of Minin University, 8(2), 6. doi:10.26795/2307-12812020-8-2-6

Gryaznova, E.V., Treushnikov, I.A., Goncharuk, A.G. (2020). The role of information culture in the formation of a cultural ideal. Perspectives of Science and Education, 43(1), 379388. doi:10.32744/pse.2020.1.27

Gumilev, L.N. (1990). Ethnogenesis and the Biosphere of the Earth. Leningrad: Leningrad State University Publishing House. https://mybook.ru/author/lev-gumilev/etnogenez-ibiosfera-zemli/read/

Hart, P., Hart, C. (2014). It is not that simple anymore: Engaging the politics of culture and identity within environmental education/Education for sustainable development (EE/ESD). Schooling for Sustainable Development across the Pacific, 37-57. doi:10.1007/978-94-017-8866-3_2

Kagan, M.N. (2013). Art, Science, and Technology in the Past, Present and Future. Leonardo, 27(5), 409-411. doi:10.2307/1576098

Kagan, M.S. (2018). Philosophy of Culture: A Study Guide for Academic Bachelor's Degree. Moscow: Yurayt. https://www.vir.nw.ru/wp-content/uploads/2018/09/Kagan-M.S.Filosofiya-kultury_filosofiya.pdf

Karopa, G. (1999). Eastern European perspective: Environmental education in Belarus. Environmental Education, 61, 31. 
Knyazeva, H. (2019). Paradigm shift in the understanding of the creative abilities of consciousness. Philosophy. Bulgarian Journal of Philosophical Education, 28(1), 1422. Retrieved from https://www.elibrary.ru/item.asp?id=37259644

Kochhar-Lindgren, K. (2015). Performing the New Sustainability Paradigm: The Role of Culture and Education. Strategies towards the New Sustainability Paradigm. Springer International Publishing. doi:10.1007/978-3-319-14699-7_8

Kochurov, B. I. (1995). European Russia: Environmental Resources and Constraints in the Former Soviet Republics. San Francisco: Westview Press.

Kochurov, B.I., Lobkovsky, V.A., Smirnov, A.Ya. (2020). Efficiency and culture of environmental management. Moscow: Rusays.

Kochurov, B.I., Vinokurova, N.F., Smirnova, V.M., Glebova, O.V., Lobkovsky, V.A. (2014). Culture of nature management: scientific and educational aspects. Problems of regional ecology, 4, 159-168. Retrieved from https://www.elibrary.ru/item.asp?id=22629182

Konchina, E. (2019). Learning outcomes for sustainable development. Encyclopedia of Sustainability in Higher Education. Cham: Springer. doi:10.1007/978-3-319-639512_220-1

Kurbatova, A.S., Rubtsova, N.V. Vershinina, A.Y., Belyaeva, T.K., Pukhova, A.G. (2020). Environmental culture development in the conditions of educational environment: Problems and perspectives. Turismo: Estudos \& Praticas, 1, 1-10.

Lerner, I.Ya. (1978). The quality of students' knowledge. What should it be like? Moscow: Znanie.

Lobashev, V.D., Talykh A.A. (2020). A frame approach in technological education. Vestnik of Minin University, 8(2), 2. doi:10.26795/2307-1281-2020-8-2-2

Loi, D., Dillon, P. (2006). Adaptive educational environments as creative spaces. Cambridge Journal of Education, 36(3), 363-381. doi:10.1080/03057640600865959

Loshchilova, A.A., Demidova, N.N., Vinokurova, N.F., Zulkharnayeva, A.V., Martilova, N.V., Shemanayev, V.A. (2019). Formation of environmental responsibility in schoolchildren in the educational space of a cultural landscape. Revista ESPACIOS, 40(31), 18. Retrieved from https://www.revistaespacios.com/a19v40n31/19403118.html

Loshchilova, A.A., Vinokurova, N.F., Zulkharnaeva, A.V., Krivdina, I.Y., Martilova, N.V., Korshunov, M.Y. (2019). Practice-oriented educational program of activities of the children environmental association as a tool to form the seventh and eighth-graders' environmental responsibility. Nuances-Estudos Sobre Educacao, 30(1), 601-631. doi:10.32930/nuances.v30i1.7095 
Makarova, E., Makarova, E., \& Korsakova, T. (2019). The role of globalization and integration in interdisciplinary research, culture and education development. Journal of History Culture and Art Research, 8(1), 111-127. doi:10.7596/taksad.v8i1.1957

Mamedov, N.M., Gay, W.C., Chumakov, A.N. (2009). Encyclopedia of Environmental Ethics and Philosophy. Detroit: CENGAGE Learning.

Mendes-Flohr, P., Schäfer, P., Urban, M. (2001). Martin Buber Werkausgabe (MBW). Berliner Akademie der Wissenschaften. Israel Academy of Sciences and Humanities.

Moiseev, N.N. (1999). On the worldview and the world perception. Ecology and Life, 4(12), 48.

Myasishchev, V.N. (2004). Relationship Psychology. Moscow: MPSI. Retrieved from https://bookap.info/genpsy/myasihchev/

Prasad, K. (2018). Culture, communication and capacity for sustainable development. K. Prasad (Eds). Communication, Culture and Ecology. Communication, Culture and Change in Asia, Vol. 6. Singapore: Springer. doi:10.1007/978-981-10-7104-1_1

Priatna, T. (2020). Demography of Madrasah Diniyah Takmiliyah and revitalizing the institutional function of Islamic education. Journal of Southwest Jiaotong University, 55(1). doi:10.35741/issn.0258-2724.55.1.54

Rocha, P., Niella, F., Keller, H., Montagnini, F., Metzel, R.N., Eibl, B., Kornel, J., Romero, F., Lopez, L., Araujo, J., Barquinero, J. (2017). Ecological Indigenous (EIK) and Scientific (ESK) Knowledge Integration as a Tool for Sustainable Development in Indigenous Communities. Experience in Misiones, Argentina. In F. Montagnini (Eds.). Integrating Landscapes: Agroforestry for Biodiversity Conservation and Food Sovereignty. Advances in Agroforestry, Vol 12. Cham: Springer. doi:10.1007/978-3-319-69371-2_10

Sánchez Galera, M.D. (2020). Conceptualising and understanding education and cultural challenges for sustainability transformation. Raising awareness on the big picture. Educational and Cultural Challenges of the European Sustainability Model. Cham: Springer. doi:10.1007/978-3-030-38716-7_4

Satterfield, T., Gregory, R., Klain, S., Roberts, M., Chan, K.M. (2012). Culture, intangibles and metrics in environmental management. Journal of Environmental Management, 117, 103-114. doi:10.1016/j.jenvman.2012.11.033

Shubinsky, V.S. (2010). Problems of interdisciplinary synthesis of knowledge about a human as a pedagogical goal. New Research in Pedagogical Sciences. Moscow: Pedagogika. Stengers, I. (2017). Civilize modernity? Whitehead and Ruminations of Common Sense. Dijon: Les presses du reel. 
Sustainable Development Goals. (n.d.). The sustainable development agenda. Retrieved from https://www.un.org/sustainabledevelopment/development-agenda/

The Hangzhou Declaration Placing Culture at the Heart of Sustainable Development Policies Adopted in Hangzhou, People’s Republic of China, on 17 May 2013. Retrieved from http://www.unesco.org/new/fileadmin/MULTIMEDIA/HQ/CLT/pdf/3_Hangzhou_De claration_EN.pdf

Timofeeva, R. (2019). On the practice of implementing non-formal adult education in the Sakha Republic (Yakutia). Journal of History Culture and Art Research, 8(4), 238-250. doi:10.7596/taksad.v8i4.2379

Van de Vijver, F.J.R., Breugelmans, S.M. (2008). Research foundations of cultural competency training. In R.H. Dana, J. Allen (Eds.). Cultural Competency Training in a Global Society. International and Cultural Psychology. New York: Springer. doi:10.1007/9780-387-79822-6_7

Van Groenou, W.W. (2005). Education amidst a cultural crisis phenomenology of life. Meeting the Challenges of the Present-Day World. Dordrecht: Springer. doi:10.1007/1-4020-3065-7_32

Vinokurova, N.F. (2014). The culture of nature management: scientific and educational aspects: a collective monograph. N. Novgorod: NGPU.

Wallace, K.J., Jago, M., Pannell, D.J., Kiatkoski Kim, M. (2020). Wellbeing, values, and planning in environmental management. Journal of Environmental Management, 277. doi:10.1016/j.jenvman.2020.111447

Wilber, K. (2007). The Integral Vision. A Very Short Introduction to the Revolutionary Integral Approach to Life, God, the Universe, and Everything. Boston; London: Shambala.

Yadov, V.A. (2014). Transformation of post-Soviet societies: What is more significant - the historically traditional or the recent past? Sociological Research, 7, 47-50. Retrieved from http://socis.isras.ru/en/article.html?id=5669

Yasvin, S.D. (2000). Psychology of the Attitude to the Nature. Moscow: Smysl. Retrieved from https://gendocs.ru/v36812/\%D1\%8F\%D1\%81\%D0\%B2\%D0\%B8\%D0\%BD_\%D0\% B2.\%D0\%B0._D0\%BF\%D1\%81\%D0\%B8\%D1\%85\%D0\%BE\%D0\%BB\%D0\%BE \%D0\%B3\%D0\%B8\%D1\%8F_\%D0\%BE\%D1\%82\%D0\%BD\%D0\%BE\%D1\%88\%D 0\%B5\%D0\%BD\%D0\%B8\%D1\%8F \%D0\%BA \%D0\%BF\%D1\%80\%D0\%B8\%D1 \%80\%D0\%BE\%D0\%B4\%D0\%B5 
Yasvin, V.A. (2012). Development of regional standard of general education social quality concept. European Journal of Contemporary Education, 1(1), 82-92. doi:10.13187/ejced.2012.1.82

Zakharova, O.V., Suvorova, L.G., Zakharov, A.V. (2020). Specifics of environmental nonformal education. Pedagogy and Education, 3, 10-28. doi:10.7256/24540676.2020.3.33617 